Article

\title{
Synthesis of Hydrotalcites from Waste Steel Slag with [Bmim]OH Intercalated for the Transesterification of Glycerol Carbonate
}

\author{
Guanhao Liu *, Jingyi Yang and Xinru Xu \\ International Joint Research Center of Green Energy Chemical Engineering, East China University of Science \\ and Technology, Meilong Road 130, Shanghai 200237, China; jyyang@ecust.edu.cn (J.Y.); \\ xrxu86@ecust.edu.cn (X.X.) \\ * Correspondence: 10110567@mail.ecust.edu.cn; Tel./Fax: +86-021-64252160
}

Received: 19 August 2020; Accepted: 18 September 2020; Published: 23 September 2020

\begin{abstract}
Ca-Mg-Al hydrotalcites were prepared by coprecipitation from Type S95 steel slag of Shanghai Baosteel Group as supports of ionic liquid in this paper. Five basic ionic liquids [Bmim] $\left[\mathrm{CH}_{3} \mathrm{COO}\right],[\mathrm{Bmim}][\mathrm{HCOO}],[\mathrm{Bmim}] \mathrm{OH},[\mathrm{Bmim}] \mathrm{Br}$ and $\mathrm{ChOH}$ were prepared and their catalytic performance on the synthesis of glycerol carbonate by transesterification between dimethyl carbonate and glycerol was investigated. The characterization results indicated that [Bmim] $\mathrm{OH}$ is the best ionic liquid (IL) for the transesterification reaction of glycerol carbonate. The hydrotalcites before and after intercalation by ionic liquid were characterized by XRD, FTIR, SEM, EDS and the IL were characterized by FT-IR, ${ }^{13} \mathrm{C}-\mathrm{NMR}$ and basicity determination via the Hammett method. The analysis results implied that the dispersion of $[\mathrm{Bmim}] \mathrm{OH}$ in hydrotalcites reduced the alkali density appropriately and facilitated the generation of glycerol carbonate. The yield of glycerol carbonate and the conversion rate of glycerol reached $95.0 \%$ and $96.1 \%$, respectively, when the molar ratio of dimethyl carbonate and glycerol was 3:1, the catalyst dosage was $3 \mathrm{wt} \%$, the reaction temperature was $75^{\circ} \mathrm{C}$ and the reaction time was $120 \mathrm{~min}$. The layered structure of hydrotalcites increased the stability of ionic liquid intercalated in carriers, thus the glycerol conversion and the GC yield still remained $91.9 \%$ and $90.5 \%$ in the fifth reaction cycle.
\end{abstract}

Keywords: steel slag; hydrotalcites; ionic liquid; transesterification

\section{Introduction}

Steel slag is the solid waste composed of $\mathrm{Ca}, \mathrm{Si}, \mathrm{Fe}, \mathrm{Mg}, \mathrm{Al}, \mathrm{Mn}, \mathrm{P}, \mathrm{O}$ and so on in the steel-making procedure [1]. The simple utilization of steel slag usually causes the loss of valuable metal resources due to the massive emissions [2]. The new door to the comprehensive utilization of steel slag will be opened up if the various metal resources can be used for the preparation of new multifunctional materials with high value [3,4].

Layered double hydroxides (LDHs), also known as hydrotalcite-like compounds, are anionic layered compounds with similar crystal structures to brucites [5]. The host layers and guest anions in LDHs are connected by noncovalent bonds. LDHs have broad application prospects in adsorption, catalysis, biomedicine and other fields due to their unique properties such as pore size tunability, interlayer anion exchangeability [6] and interlayer cation compatibility [7]. Specially, LDHs are often used as carriers in the catalysis field due to their layered structures [8].

Carbonate glycerol (GC) is widely used in food, medicine, plastics, military, new materials and new energy as a special bio-based chemical with high boiling point, low freezing point, low volatility, low flammability and strong polarity [9]. The transesterification of glycerol with dimethyl carbonate 
(DMC) over basic catalysts is considered to be an effective method for GC synthesis under mild conditions [10]. The only reaction byproduct methanol is easily separated from the product mixture. Meanwhile, toxic substances, relatively high reaction pressure and other harsh reaction conditions can be avoided in the process [11]. The preparation of a catalyst with high activity and stability is the necessary requirement for large-scale production of GC [12].

Ionic liquid has been of wide concern in the field of catalysis in recent years due to its mild reaction conditions, high-efficiency selectivity and simple operation process [13]. However, it is difficult to separate ionic liquid from the homogeneous system after reaction [14]. The immobilization of ionic liquid can not only retain remarkable catalytic performance, but also overcome the separation difficulties [15]. Meanwhile, new properties and characteristics of catalysts will be derived via the synergism between ionic liquid and carriers [16].

In this paper, alkaline ionic liquids with different structures were designed and synthesized for the transesterification of dimethyl carbonate and glycerol to produce glycerol carbonate. The effect of different ions on the catalytic ability was investigated. $\mathrm{Ca}-\mathrm{Mg}$-Al hydrotalcites were prepared from waste steel slag and used as carriers for the intercalation of ionic liquid. This process recycled the waste steel slag, reduced the synthesis cost of hydrotalcites and solved the separation problem of ionic liquid.

\section{Results and Discussion}

\subsection{Characterization of Ionic Liquid}

\subsection{1. ${ }^{13} \mathrm{C}-\mathrm{NMR}$ analysis of Ionic Liquid}

Figure 1 showed the ${ }^{13} \mathrm{C}-\mathrm{NMR}$ spectra of $[\mathrm{Bmim}]\left[\mathrm{CH}_{3} \mathrm{COO}\right],[\mathrm{Bmim}][\mathrm{HCOO}],[\mathrm{Bmim}] \mathrm{OH}$, [Bmim] $\mathrm{Br}$ and $\mathrm{ChOH}$. The peaks at $67.68 \mathrm{ppm}$ and $58.86 \mathrm{ppm}$ were the resonance signals of methylene on quaternary ammonium cations, and the chemical shift of methyl on quaternary ammonium cations was $54.66 \mathrm{ppm}$ in the ${ }^{13} \mathrm{C}$-NMR spectra of $\mathrm{ChOH}$. In the other four spectra, the characteristic peaks at $138.80 \mathrm{ppm}, 124.94 \mathrm{ppm}$ and $120.24 \mathrm{ppm}$ corresponded to the chemical shifts of carbon on the imidazole ring. The resonance signals of carbon on the methylene linked to the imidazole ring were $48.66 \mathrm{ppm}$, $31.10 \mathrm{ppm}$ and $20.50 \mathrm{ppm}$. The peaks appeared where $\delta$ was $36.88 \mathrm{ppm}$, and $13.87 \mathrm{ppm}$ can be attributed to the methyl carbon on imidazole ring branch. The carbon chemical shifts of acetate were $177.14 \mathrm{ppm}$ and $21.83 \mathrm{ppm}$ in the NMR spectrum of $[\mathrm{Bmim}]\left[\mathrm{CH}_{3} \mathrm{COO}\right]$. The peak where $\delta$ was $166.35 \mathrm{ppm}$ can be ascribed to the resonance signals of formate in the NMR spectrum of [Bmim][HCOO]. The four synthesized products had similar structure of 1-butyl-3-methyl imidazole cation while the anions were bromine, hydroxyl, acetate and formate, respectively, according to the above NMR analysis results.

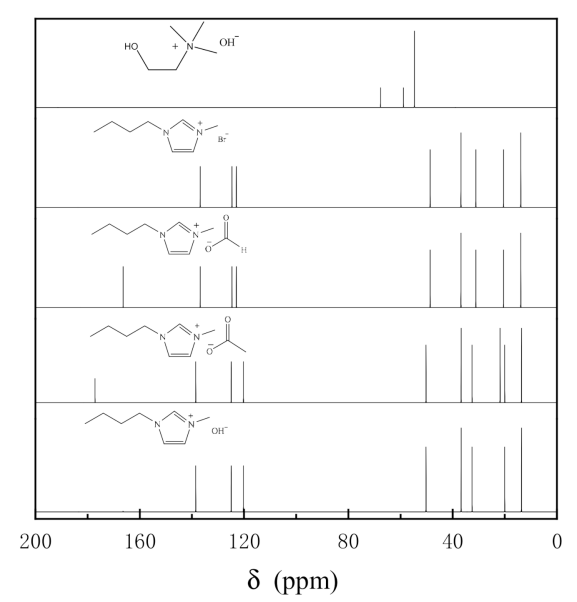

Figure 1. ${ }^{13} \mathrm{C}-\mathrm{NMR}$ spectra of $[\mathrm{Bmim}] \mathrm{OH},[\mathrm{Bmim}]\left[\mathrm{CH}_{3} \mathrm{COO}\right],[\mathrm{Bmim}][\mathrm{HCOO}],[\mathrm{Bmim}] \mathrm{Br}$ and $\mathrm{ChOH}$. 


\subsubsection{FT-IR Analysis of Ionic Liquid}

The FT-IR spectra of different ionic liquids were displayed in Figure 2. The related characteristic absorption peaks of imidazole were shown in the spectra of $[\mathrm{Bmim}]\left[\mathrm{CH}_{3} \mathrm{COO}\right]$, $[\mathrm{Bmim}][\mathrm{HCOO}]$, $[\mathrm{Bmim}] \mathrm{OH}$ and $[\mathrm{Bmim}] \mathrm{Br}$. The stretching vibration peaks of unsaturated $\mathrm{C}-\mathrm{H}$ on imidazole rings appeared at $3123 \mathrm{~cm}^{-1}$ and $3082 \mathrm{~cm}^{-1}$. The absorption peaks at $2965 \mathrm{~cm}^{-1}, 2954 \mathrm{~cm}^{-1}$ and $2866 \mathrm{~cm}^{-1}$ were corresponded to the stretching vibration of saturated C-H bond on branch chain. The characteristic peaks at $1645 \mathrm{~cm}^{-1}$ and $1163 \mathrm{~cm}^{-1}$ were attributed to the stretching vibration of $\mathrm{C}-\mathrm{N}$ and $\mathrm{C}=\mathrm{C}$ on imidazole ring. Duan [17] reported similar results about the imidazolium cation. The absorption peak at about $3500 \mathrm{~cm}^{-1}$ was caused by the stretching vibration of hydroxyl. In the infrared spectra of [Bmim] $\left[\mathrm{CH}_{3} \mathrm{COO}\right]$ and [Bmim][HCOO], the absorption peak at $1375 \mathrm{~cm}^{-1}$ was ascribed to the asymmetric stretching vibration of $\mathrm{C}-\mathrm{O}$ in carboxylate. The absorption peak at $1656 \mathrm{~cm}^{-1}$ was corresponded to N-C stretching vibration of quaternary ammonium cations in the FT-IR spectra of $\mathrm{ChOH}$. The stretching vibration peaks of methylene and methyl on the branched chain of quaternary ammonium cation appeared at $2989 \mathrm{~cm}^{-1}$ and $2699 \mathrm{~cm}^{-1}$. All the above indicated that the ionic liquid had been synthesized successfully.

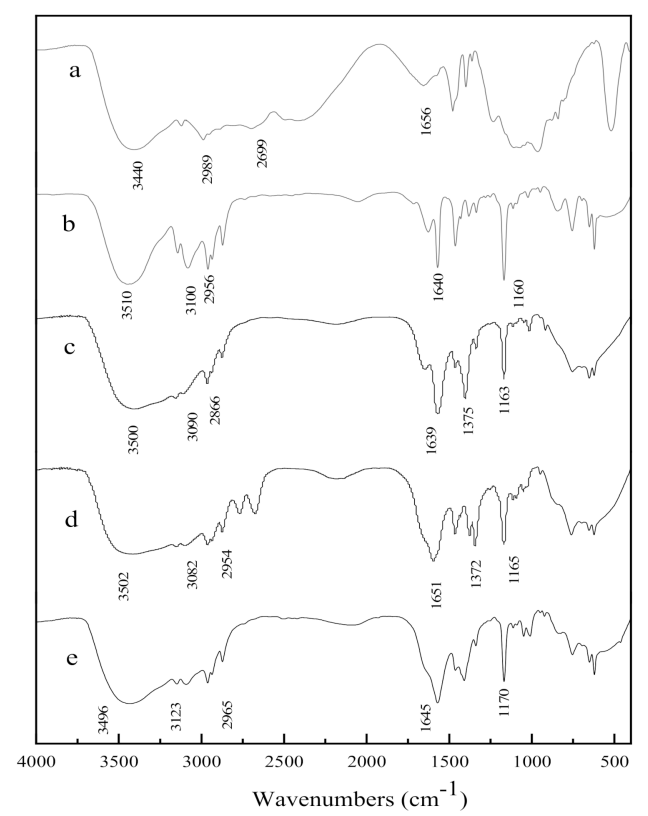

Figure 2. FT-IR spectra of $\mathrm{ChOH}(\mathbf{a}),[\mathrm{Bmim}] \mathrm{Br}(\mathbf{b}),[\mathrm{Bmim}][\mathrm{HCOO}](\mathbf{c}),[\mathrm{Bmim}]\left[\mathrm{CH}_{3} \mathrm{COO}\right](\mathbf{d})$ and $[\mathrm{Bmim}] \mathrm{OH}(\mathbf{e})$.

\subsubsection{Results of Basicity of Ionic Liquids}

The catalyst basicity was tested, and the influence on the reaction activity was studied in this section. The basic amount of [Bmim] $\mathrm{Br}$, [Bmim] [HCOO], [Bmim] $\left[\mathrm{CH}_{3} \mathrm{COO}\right], \mathrm{ChOH}$ and $[\mathrm{Bmim}] \mathrm{OH}$ was $0.69 \mathrm{mmol} / \mathrm{g}, 0.87 \mathrm{mmol} / \mathrm{g}, 0.92 \mathrm{mmol} / \mathrm{g}, 1.09 \mathrm{mmol} / \mathrm{g}$ and $1.17 \mathrm{mmol} / \mathrm{g}$, respectively, in Table 1 . The glycerol conversion and the GC yield mounted up with the increase of basicity while the reaction selectivity decreased because glycerol carbonate was further decarboxylated to generate glycidol in the strong alkaline environment. The intercalation of ionic liquid in hydrotalcites reduced the alkali density appropriately, which not only helped to improve the selectivity, but also solved the separation problem of ionic liquid. 
Table 1. Effect of ionic liquid basicity on glycerol conversation and carbonate glycerol (GC) yield.

\begin{tabular}{|c|c|c|c|c|}
\hline Catalyst & $\begin{array}{c}\text { Glycerol Conv. } \\
(\%)\end{array}$ & $\begin{array}{c}\text { GC Yield } \\
(\%)\end{array}$ & $\begin{array}{l}\text { Basic Amount } \\
(\mathrm{mmol} / \mathrm{g})\end{array}$ & $\begin{array}{c}\text { Basic Strength } \\
\text { (H_) }\end{array}$ \\
\hline [Bmim]HCOO & 81.6 & 81.1 & 0.87 & $\mathrm{H}_{-}<9.8$ \\
\hline$[\mathrm{Bmim}]\left[\mathrm{CH}_{3} \mathrm{COO}\right]$ & 90.5 & 90.3 & 0.92 & $9.8<\overline{\mathrm{H}}_{-}<15.0$ \\
\hline$[\mathrm{Bmim}] \mathrm{OH}$ & 97.5 & 92.1 & 1.17 & $18.4<\mathrm{H}_{-}<26.5$ \\
\hline [Bmim] $\mathrm{Br}$ & 75.2 & 75.0 & 0.69 & $\mathrm{H}_{-}<9.8$ \\
\hline $\mathrm{ChOH}$ & 96.5 & 91.4 & 1.09 & $18.4<\mathrm{H}_{-}<26.5$ \\
\hline
\end{tabular}

\subsection{Characterization of IL-CaMgAl}

\subsubsection{XRD Analysis}

Figure 3 was the XRD patterns of pure hydrotalcites and ionic liquid intercalated hydrotalcites. IL-CaMgAl still had the characteristic peaks of hydrotalcite lattice planes (003), (006), (009), (015), (018), (110) and (113) [6]. The position of each characteristic diffraction peak in IL-CaMgAl was slightly shifted but can be clearly distinguished compared with the XRD spectrum of pure hydrotalcites, which indicated that the intercalation of [Bmim] $\mathrm{BH}$ did not change the crystal structure of hydrotalcites.

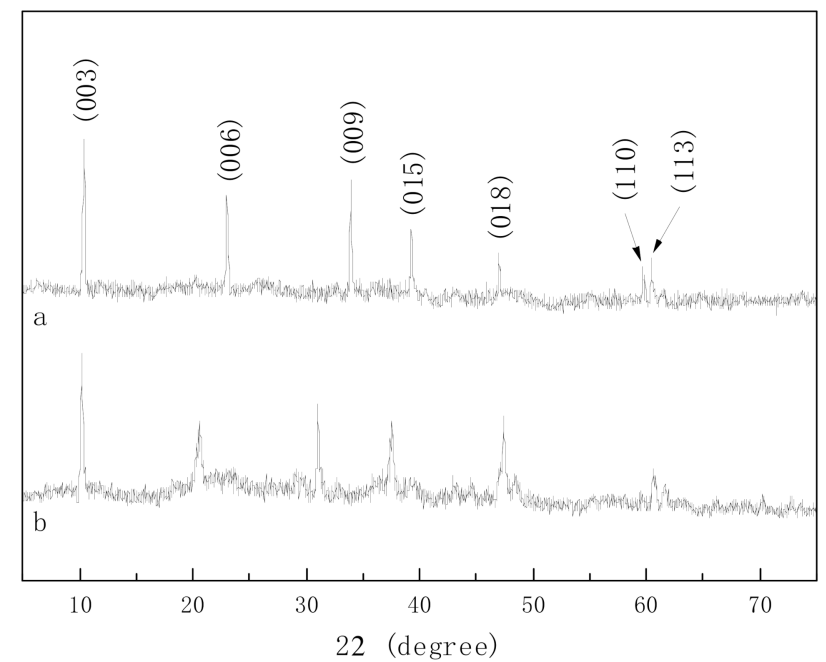

Figure 3. XRD patterns of pure hydrotalcites (a) and IL-CaMgAl (b).

\subsubsection{FT-IR Analysis}

FT-IR spectra of CaMgAl hydrotalcites before and after intercalation by ionic liquid were shown in Figure 4. The absorption peak of pure hydrotalcites at $3470 \mathrm{~cm}^{-1}$ was related to hydroxyl stretching vibration linked to metal cations. The absorption vibration peak of carbonyl in carbonates was observed at $1430 \mathrm{~cm}^{-1}$. The characteristic peaks of imidazole ionic liquid appeared, obviously, on the infrared spectrum of hydrotalcites after intercalation by [Bmim] $\mathrm{OH}$. The absorption peaks at $3250 \mathrm{~cm}^{-1}$ and $3090 \mathrm{~cm}^{-1}$ corresponded to the unsaturated C-H on imidazole rings. The stretching vibration peaks at $2960 \mathrm{~cm}^{-1}, 2930 \mathrm{~cm}^{-1}$ and $2880 \mathrm{~cm}^{-1}$ were attributed to the saturated carbon-hydrogen bond on the branch chain of imidazole rings. The absorption peaks at $1567 \mathrm{~cm}^{-1}$ and $1164 \mathrm{~cm}^{-1}$ were ascribed to $\mathrm{C}=\mathrm{N}$ and $\mathrm{C}-\mathrm{C}$ on imidazole rings, respectively. All indicated that [Bmim]OH had been intercalated into hydrotalcites successfully. 


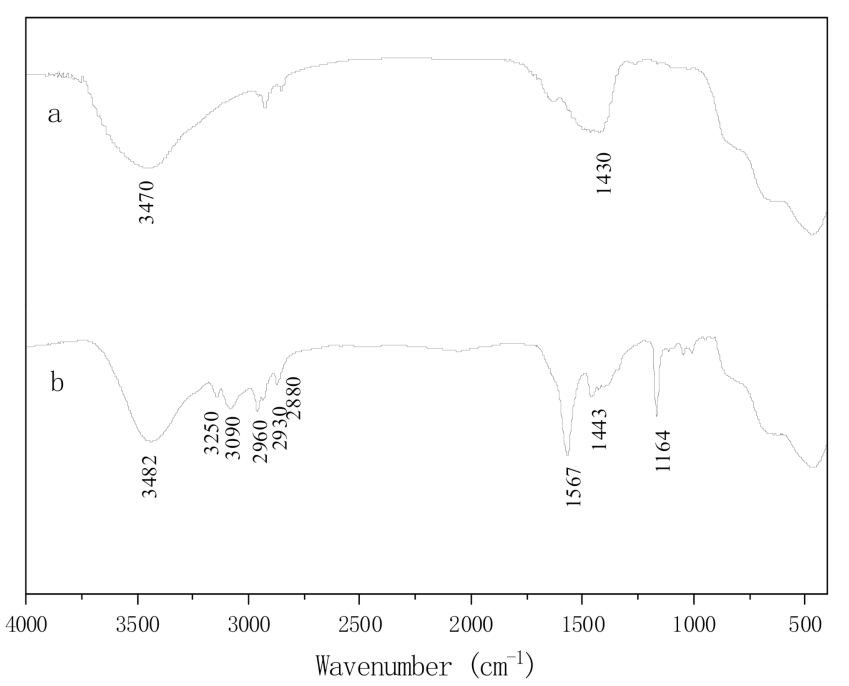

Figure 4. FT-IR spectra of pure hydrotalcites (a) and IL-CaMgAl (b).

\subsubsection{Element Analysis}

Table 2 was the main element analysis of pure hydrotalcites and IL-CaMgAl. The contents of oxygen, calcium, aluminum, carbon and magnesium in the pure hydrotalcites were $45.49 \mathrm{wt} \%$, $28.74 \mathrm{wt} \%, 9.99 \mathrm{wt} \%, 6.11 \mathrm{wt} \%$ and $4.04 \mathrm{wt} \%$, respectively, while the contents of oxygen, calcium, carbon, aluminum, nitrogen and magnesium in the IL-CaMgAl were $41.93 \mathrm{wt} \%, 27.53 \mathrm{wt} \%, 12.30 \mathrm{wt} \%$, $7.98 \mathrm{wt} \%, 5.25 \mathrm{wt} \%$ and $3.66 \mathrm{wt} \%$, respectively. The occurrence of nitrogen and the increase of carbon indicated that the ionic liquid had immobilized in the hydrotalcites since [Bmim]OH contained a large amount of carbon and nitrogen elements.

Table 2. Surface element content of CaMgAl and IL-CaMgAl.

\begin{tabular}{cccccccc}
\hline Element (wt.\%) & $\mathbf{C}$ & $\mathbf{N}$ & $\mathbf{O}$ & $\mathbf{M g}$ & Al & Ca & Others \\
\hline CaMgAl & 6.11 & NA * & 45.49 & 4.04 & 9.99 & 28.74 & 5.63 \\
IL-CaMgAl & 12.30 & 5.25 & 41.93 & 3.66 & 7.98 & 27.53 & 1.35 \\
\hline \multicolumn{7}{r}{ NA means the element content can not be detected by the instrument. }
\end{tabular}

\subsubsection{SEM Analysis}

The petaloid layered structures was the characteristic morphology of hydrotalcites [7]. The polygonal or circular lamellas can be seen clearly in the SEM images of pure hydrotalcites in Figure 5. The layered morphology was still maintained after intercalation of [Bmim]OH in the SEM images of IL-CaMgAl, but the lamellas were distorted to some extent.
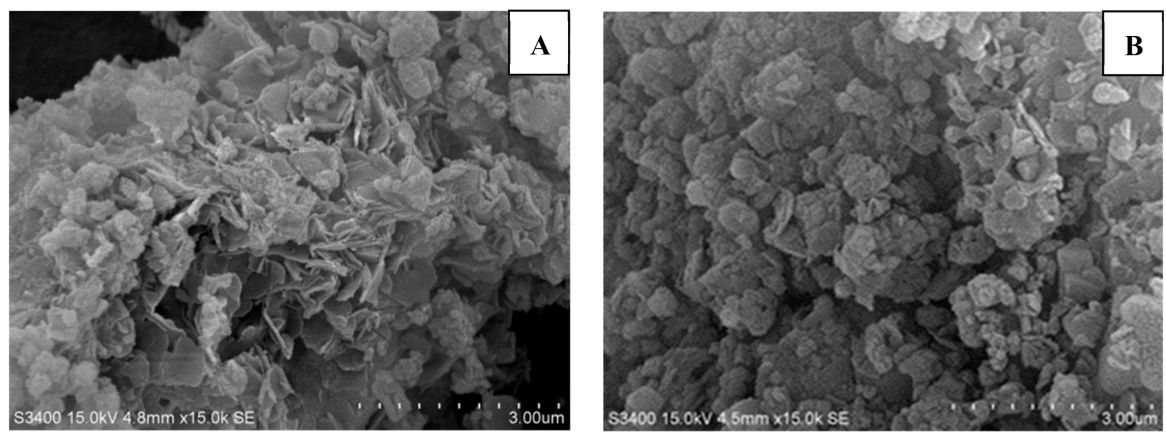

Figure 5. SEM images of pure hydrotalcites (A) and IL-CaMgAl (B). 


\subsection{Transesterification of Glycerol and Dimethyl Carbonate}

The intercalation of [Bmim] $\mathrm{OH}$ with strong alkalinity changed the catalytic activity of hydrotalcites, obviously. The esterification of dimethyl carbonate and glycerol was carried out catalyzed by IL-CaMgAl and pure hydrotalcites respectively under the condition that the catalyst dosage was $3 \mathrm{wt} \%$, the molar ratio of DMC and glycerol was 3:1, the reaction time was $120 \mathrm{~min}$ and the reaction temperature was $75{ }^{\circ} \mathrm{C}$ in order to investigate the influence of ionic liquid intercalation on esterification. The reaction results were presented in Figure 6.

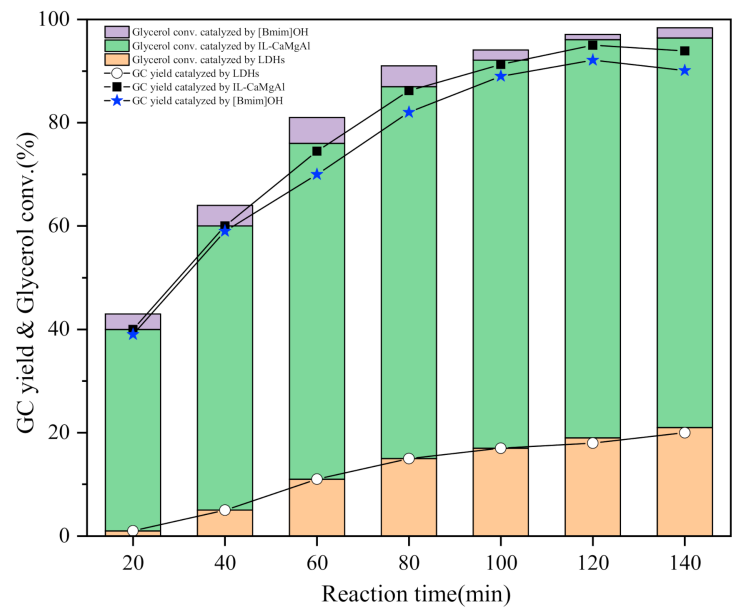

Figure 6. Transesterification of dimethyl carbonate and glycerol catalyzed by [Bmim]OH, layered double hydroxides (LDHs) and IL-CaMgAl.

The conversion rate of glycerol and the yield of glycerol carbonate catalyzed by IL-CaMgAl were much higher than that by pure hydrotalcites in the same reaction time. The glycerol conversion rate and the GC yield catalyzed by pure hydrotalcites were both at a low level all along. The conversion rate of glycerol catalyzed by ionic liquid intercalated hydrotalcites reached $60.1 \%$ without by-product when the reaction lasted for $40 \mathrm{~min}$. The GC yield was $95.0 \%$ and the glycerol conversion was $96.1 \%$ when the reaction time was $120 \mathrm{~min}$. However, the yield of GC decreased slightly although the conversion rate of glycerol increased when the reaction time continued to mount up since the further decarboxylation of glycerol carbonate generated glycidol in strong alkaline environment. The optimal reaction time was 120 min under the research conditions based on the above experimental results. The catalytic performance comparison of different catalysts was listed in Table 3.

Table 3. Comparison of IL-CaMgAl with reported catalysts in transesterification of dimethyl carbonate (DMC) and glycerol.

\begin{tabular}{ccccccc}
\hline Catalyst & $\begin{array}{c}\text { Catalyst } \\
\text { Dosage } \\
(\mathbf{w t .} \%)\end{array}$ & $\begin{array}{c}\text { Reaction } \\
\text { Temperature } \\
\left({ }^{\circ} \mathbf{C}\right)\end{array}$ & $\begin{array}{c}\text { Molar Ratio } \\
\text { of DMC to } \\
\text { Glycerol }\end{array}$ & $\begin{array}{c}\text { Reaction Time } \\
\text { (min) }\end{array}$ & $\begin{array}{c}\text { GC } \\
\text { Yield } \\
(\mathbf{\%})\end{array}$ & Ref. \\
\hline $\mathrm{CaO}$ & 3 & 75 & $2: 1$ & 30 & 90.2 & {$[18]$} \\
$\mathrm{Na}_{2} \mathrm{SiO}_{3}-200$ & 5 & 75 & $4: 1$ & 150 & 95.5 & {$[19]$} \\
Calcined & 6 & 75 & $3: 1$ & 90 & 94.0 & {$[20]$} \\
Dolomite & 10 & 70 & $3: 1$ & 240 & 80.0 & {$[21]$} \\
$\mathrm{NaY}$ zeolite & 3 & 75 & $3: 1$ & 90 & 96.2 & This work \\
IL-CaMgAl & & & & & & \\
\hline
\end{tabular}

\subsection{Reusability Test of IL-CaMgAl}

Continuous industrial reaction required high stability of catalyst materials to resist rapid deactivation and leaching of active sites. The cycle experiment was carried out when the molar 
ratio of DMC and glycerol was 3:1, the catalyst dosage was $3 \mathrm{wt} \%$, the reaction temperature was $75^{\circ} \mathrm{C}$ and the reaction time was $120 \mathrm{~min}$. IL-CaMgAl was washed with methanol after each reaction cycle. Figure 7 displayed the XRD patterns and FT-IR spectra of fresh catalyst and five times reused catalyst. The crystal morphology of catalyst after five cycles was almost identical to the fresh catalyst. However, the adsorption peak of [Bmim] $\mathrm{OH}$ became weak and the stretching vibration peak of ester group at $1710 \mathrm{~cm}^{-1}$ appeared in the FT-IR spectrum of five times reused catalysts, which indicated the loss of active components and the adhesion of organics.
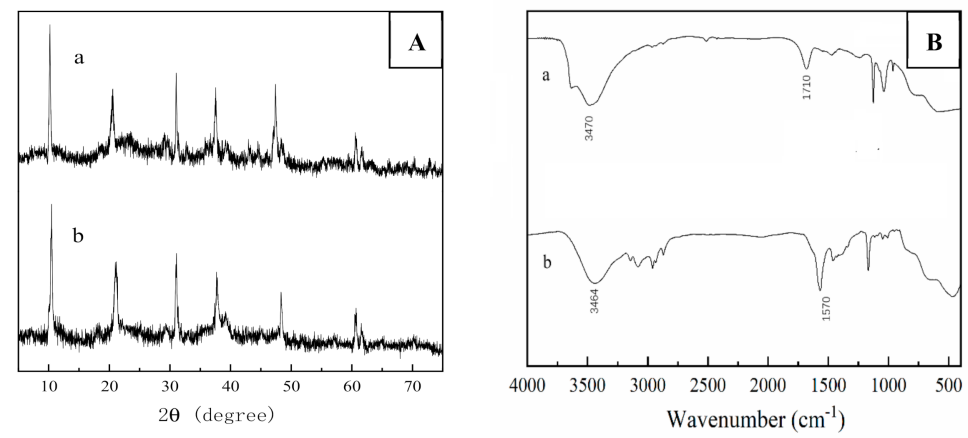

Figure 7. XRD patterns (A) and FT-IR spectra (B) of five times reused catalyst (a) and fresh catalyst (b).

Figure 8 showed the change of catalytic activity of IL-CaMgAl in the five cycles. The catalyst remained $91.9 \%$ glycerol conversion rate and $90.5 \%$ GC yield in the fifth reaction cycle, which meant IL-CaMgAl had remarkable reusability in the continuous reaction. The hydrotalcites with layered structures can immobilized the ionic liquid and, thus, reduce the loss of active components in the catalyst.

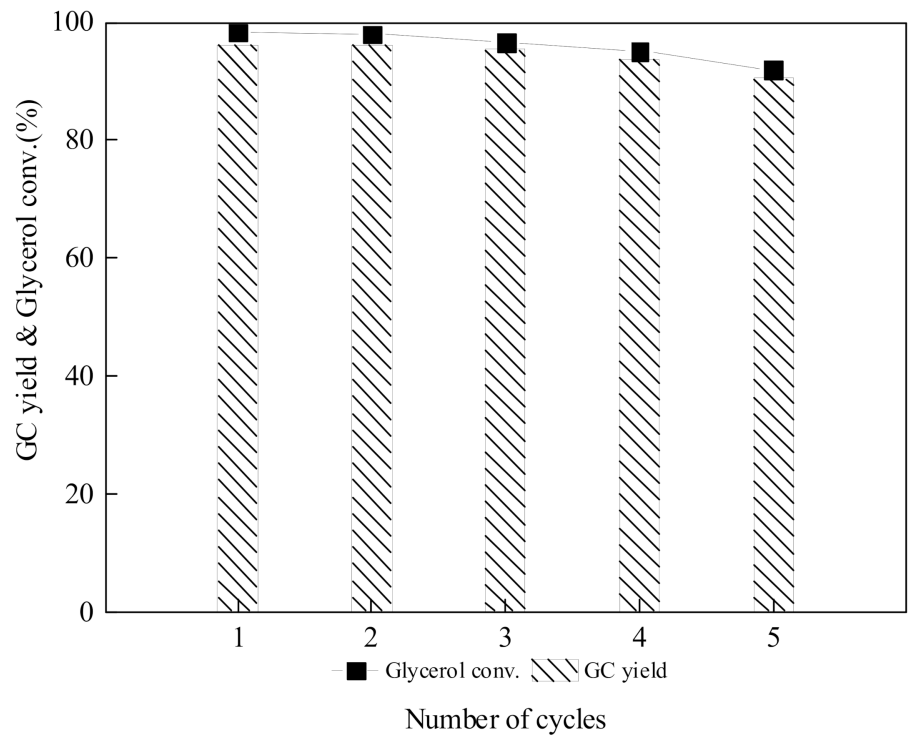

Figure 8. Reusability of IL-CaMgAl.

\section{Experimental}

\subsection{Preparation of Ionic Liquid}

First, 1-methylimidazole $(0.05 \mathrm{~mol})$ was added into the four-neck flask with the condenser tube and heated slowly to $70^{\circ} \mathrm{C}$. Some $n$-butylbromide, in the constant pressure funnel, was added dropwise at 1:1.1 molar ratio of 1 -methylimidazole to $n$-butylbromide. The reaction was carried out at $70{ }^{\circ} \mathrm{C}$ 
under the atmosphere of nitrogen. The yellowish intermediate [Bmim] $\mathrm{Br}$ was obtained after washing with ethyl acetate and drying in a vacuum oven at $70^{\circ} \mathrm{C}$ for $24 \mathrm{~h}$.

[Bmim] $\mathrm{Br}(0.03 \mathrm{~mol})$ and potassium acetate were weighed at the molar ratio of 1:1 and dissolved in methanol. The reaction lasted for $8 \mathrm{~h}$ at $25^{\circ} \mathrm{C}, 10 \mathrm{~mL}$ ether was added after reaction and the white precipitate was removed by filtration. The filtrate was evaporated for $1 \mathrm{~h}$ at $55^{\circ} \mathrm{C}$ and dried in the vacuum oven at $70{ }^{\circ} \mathrm{C}$ for $24 \mathrm{~h}$ to obtain ionic liquid [Bmim] [ $\mathrm{CH}_{3} \mathrm{COO}$. [Bmim] [HCOO] and [Bmim] $\mathrm{OH}$ can be prepared by changing the above-mentioned potassium acetate into potassium formate and sodium hydroxide, respectively.

The quaternary ammonium ionic liquid $\mathrm{ChOH}$ was synthesized by using choline chloride and sodium hydroxide as raw materials at the molar ratio of 1:1. Choline chloride and sodium hydroxide were weighed and dissolved in dichloromethane solution. The dichloromethane was removed by rotary evaporation after the reaction, and $\mathrm{ChOH}$ was obtained after washing with ethyl acetate, filtering and drying.

\subsection{Preparation of $\mathrm{Ca}-\mathrm{Mg}-\mathrm{Al}$ Hydrotalcites Intercalated by [Bmim]OH}

Hydrotalcites were synthesized by coprecipitation method in this study. The steel slag from Shanghai Baosteel Group was dissolved in $34 \mathrm{wt} \%$ nitric acid solution to prepare solution A. Appropriately, $\mathrm{NaOH}$ and $\mathrm{Na}_{2} \mathrm{CO}_{3}$, at the molar ratio of 1:16, was dissolved in deionized water to prepare solution $\mathrm{B}$. Then, $50 \mathrm{~mL}$ deionized water and $[\mathrm{Bmim}] \mathrm{OH}$ was add into a four-neck flask with stirring devices. Solution A and solution B were dropped by double-titration method. The system temperature was kept at $70{ }^{\circ} \mathrm{C}$, and the $\mathrm{pH}$ value was kept between 10 and 11 during titration. The obtained white slurry was aged in a constant-temperature water bath at $70{ }^{\circ} \mathrm{C}$ for $24 \mathrm{~h}$. The hydrotalcites intercalated by ionic liquid were synthesized after filtering, washing with deionized water and drying in the vacuum oven at $70{ }^{\circ} \mathrm{C}$ for $24 \mathrm{~h}$. Pure hydrotalcites can be prepared without adding ionic liquid in the coprecipitation.

\subsection{Characterization Methods}

The crystallite sizes of solid catalyst were characterized by X-ray diffraction (XRD) on Rigaku $\mathrm{D} / \mathrm{max} 2550 \mathrm{VB} / \mathrm{PC}$ (Rigaku International Corporation, Tokyo, Japan) with CuK $\alpha$ radiation $(\lambda=0.154 \mathrm{~nm}$, $100 \mathrm{~mA}, 45 \mathrm{kV})$. The scanning range was $10-80^{\circ}(2 \theta)$ with a rate of $0.02^{\circ} / \mathrm{s}$. Surface elements were measured by Edax Falcon energy dispersive spectrometer (EDS) (EDAX Co., Ltd., Mahwah, NJ, USA). The morphologies of hydrotalcites was observed by scanning electron microscope (SEM, Hitachi S-3400N, Hitachi Co., Ltd., Tokyo, Japan). Fourier transform infrared (FT-IR) absorption spectra of the samples were determined by Nicolet Magna-IR 550 via KBr pellet (Thermo Fisher Scientific, Waltham, MA, USA). Avance 500 nuclear magnetic resonance spectrometer of Bruker company in Germany was used to determine the ${ }^{13} \mathrm{C}-\mathrm{NMR}$ spectrum of samples. Hammett indicators including 4-nitroaniline $\left(\mathrm{H}_{-}=18.4\right)$, 2.4-dinitroaniline $\left(\mathrm{H}_{-}=15.0\right)$, phenolphthalein $\left(\mathrm{H}_{-}=9.8\right)$ and 4-chloroaniline $\left(\mathrm{H}_{-}=26.5\right)$ were used to measure the basic strength of ionic liquid by various color. The ionic liquid was diluted with deionized water and titrated with hydrochloric acid standard solution using phenolphthalein as indicator. The alkali amount can be calculated by the amount of hydrochloric acid consumed.

\subsection{Transesterification Procedure}

Glycerol and dimethyl carbonate according to the molar ratio of 1:3 was added into the flask with the stirring device and reflux device. The mixture was heated to $75^{\circ} \mathrm{C}$ under the atmosphere of nitrogen. Then, $3 \mathrm{wt} \% \mathrm{IL}-\mathrm{CaMgAl}$ was added to catalyze the transesterification between glycerol and dimethyl carbonate. The product was separated from solid catalyst after $120 \mathrm{~min}$ by centrifugation and analyzed by gas chromatography. The gas chromatograph (Jinghe GC-7860, Jing He Analysis Instrument Co., Ltd., Shanghai, China) was equipped with a flame ionization detector (FID) (Agilent 
Technologies Inc., Santa Clara, CA, USA) and a capillary column (HP-PONA, $50 \mathrm{~m}$ by $0.200 \mathrm{~mm}$ by $0.50 \mu \mathrm{m})$. The injection temperature and detector temperature were $325^{\circ} \mathrm{C}$ and $280{ }^{\circ} \mathrm{C}$, respectively.

\section{Conclusions}

The partial metal elements such as $\mathrm{Ca}, \mathrm{Mg}$ and $\mathrm{Al}$ in waste steel slag can be utilized effectively by preparing the environment-friendly catalyst in this paper. The intercalation of ionic liquid $[\mathrm{Bmim}] \mathrm{OH}$ adjusted the basicity of hydrotalcites and improved the GC yield in the transesterification of dimethyl carbonate and glycerol. The highest yield of glycerol carbonate can reach $95.0 \%$ under the condition that the molar ratio of DMC and glycerol was $3: 1$, the catalyst dosage was $3 \mathrm{wt} \%$, the reaction time was $120 \mathrm{~min}$ and the reaction temperature was $75^{\circ} \mathrm{C}$. Meanwhile, the supported solid catalyst also solved the separation difficulty and loss problem of ionic liquid. The conversion rate of glycerol and the yield of GC still remained $91.9 \%$ and $90.5 \%$ after five cycles catalyzed by IL-CaMgAl. The significant reusability and high catalytic activity of IL-CaMgAl made it meet the requirements of continuous production and have extensive application perspective in industry. However, all experiments in this paper were carried out in a lab scale, thus the pilot-scale study was necessary for the further research.

Author Contributions: Conceptualization, G.L. and X.X.; methodology, G.L.; software, J.Y.; validation, G.L., J.Y. and X.X.; formal analysis, G.L.; investigation, G.L.; resources, J.Y.; data curation, X.X.; writing一original draft preparation, G.L.; writing-review and editing, J.Y.; visualization, X.X.; supervision, G.L.; project administration, G.L.; funding acquisition, J.Y. All authors have read and agreed to the published version of the manuscript.

Funding: This research received no external funding.

Conflicts of Interest: The authors declare no conflict of interest.

\section{References}

1. Tae, S.J;; Morita, K. Immobilization of $\mathrm{Cr}(\mathrm{VI})$ in stainless steel slag and $\mathrm{Cd}$, $\mathrm{As}$, and $\mathrm{Pb}$ in wastewater using blast furnace slag via a hydrothermal treatment. Met. Mater. Int. 2017, 23, 576-581. [CrossRef]

2. Yüksel, İ. A review of steel slag usage in construction industry for sustainable development. Environ. Dev. Sustain. 2017, 19, 369-384. [CrossRef]

3. Wang, L.; Liu, W.; Hu, J. Indirect mineral carbonation of titanium-bearing blast furnace slag coupled with recovery of $\mathrm{TiO}_{2}$ and $\mathrm{Al}_{2} \mathrm{O}_{3}$. Chin. J. Chem. Eng. 2017, 26, 583-592. [CrossRef]

4. Purohit, A.; Satapathy, A. Dry sliding wear characteristics of epoxy composites filled with steel industry slag and sludge particles: A comparative study. Mater. Today Proc. 2018, 5, 11906-11913. [CrossRef]

5. Zhang, F.; Du, N.; Li, H. Sorption of $\mathrm{Cr}(\mathrm{VI})$ on Mg-Al-Fe layered double hydroxides synthesized by a mechanochemical method. RSC Adv. 2014, 4, 46823-46830. [CrossRef]

6. Yu, X.Y.; Luo, T.; Jia, Y. Three-dimensional hierarchical flower-like Mg-Al-layered double hydroxides: Highly efficient adsorbents for $\mathrm{As}(\mathrm{V})$ and $\mathrm{Cr}(\mathrm{VI})$ removal. Nanoscale 2012, 4, 3466-3474. [CrossRef]

7. Hussein, M.Z.B.; Zainal, Z.; Yahaya, A.H. Controlled release of a plant growth regulator, $\alpha$-naphthaleneacetate from the lamella of Zn-Al-layered double hydroxide nanocomposite. J. Control. Release 2012, 82, 417-427. [CrossRef]

8. Nowicki, J.; Lach, J.; Organek, M.; Sabura, E. Transesterification of rapeseed oil to biodiesel over Zr-doped MgAl hydrotalcites. Appl. Catal. A 2016, 524, 17-24. [CrossRef]

9. Wan, Y.; Lei, Y.; Lan, G.; Liu, D.; Li, G.; Bai, R. Synthesis of glycerol carbonate from glycerol and dimethyl carbonate over DABCO embedded porous organic polymer as a bifunctional and robust Catalyst. Appl. Catal. A 2018, 562, 267-275. [CrossRef]

10. Wang, S.; Wan, J.; Sun, P.; Xu, L.; Okoye, P.U.; Li, S. Disposable baby diapers waste derived catalyst for synthesizing glycerol carbonate by the transesterification of glycerol with dimethyl carbonate. J. Cleaner Prod. 2019, 211, 330-341. [CrossRef]

11. $\mathrm{Liu}, \mathrm{J}$; $\mathrm{He}, \mathrm{D}$. Transformation of $\mathrm{CO}_{2}$ with glycerol to glycerol carbonate by a novel $\mathrm{ZnWO}_{4}-\mathrm{ZnO}$ catalyst. J. CO2 Util. 2018, 26, 370-379. [CrossRef]

12. Chaves, D.M.; Márcio, J.; Da, S. A selective synthesis of glycerol carbonate from glycerol and urea over $\mathrm{Sn}(\mathrm{OH})_{2}$ : A solid and recyclable in situ generated catalyst. New J. Chem. 2019, 43, 3698-3706. [CrossRef] 
13. Olkiewica, M.; Plechkova, N.V.; Earle, M.J.; Fabregat, A.; Stüber, F. Biodiesel production from sewage sludge lipids catalysed by Brønsted acidic ionic liquids. Appl. Catal. B 2016, 181, 738-746. [CrossRef]

14. Zhang, P.; Liu, Y.; Fan, M.; Jiang, P. Catalytic performance of a novel amphiphilic alkaline ionic liquid for biodiesel production: Influence of basicity and conductivity. Renew. Energ. 2016, 86, 99-105. [CrossRef]

15. Shirani, M.; Semnani, A.; Habibollahi, S. Synthesis and application of magnetic NaY zeolite composite immobilized with ionic liquid for adsorption desulfurization of fuel using response surface methodology. J. Porous Mat. 2016, 23, 701-712. [CrossRef]

16. Yao, H.; Wang, G.; Zuo, C. Deep hydrodenitrification of pyridine by solid catalyst coupling with ionic liquids under mild conditions. Green Chem. 2017, 19, 1692-1700. [CrossRef]

17. Duan, J.; Sun, Y.; Shi, L. Three different types of heterocycle of nitrogen-containing alkaline ionic liquids treatment of acid oil to remove naphthenic acids. Catal Today. 2013, 212, 180-185. [CrossRef]

18. Simanjuntak, F.S.H.; Kim, T.K.; Lee, S.D.; Ahn, B.S. CaO-Catalyzed synthesis of glycerol carbonate from glycerol and dimethyl carbonate: Isolation and characterization of an active Ca species. Appl. Catal. A 2011, 401, 220-225. [CrossRef]

19. Wang, S.; Hao, P.; Li, S.; Zhang, A.; Guan, Y.; Zhang, L. Synthesis of glycerol carbonate from glycerol and dimethyl carbonate catalyzed by calcined silicates. Appl. Catal. A 2017, 542, 174-181. [CrossRef]

20. Algoufi, Y.T.; Kabir, G.; Hameed, B.H. Synthesis of glycerol carbonate from biodiesel by-product glycerol over calcined Dolomite. J. Taiwan Inst. Chem. Eng. 2017, 70, 179-187. [CrossRef]

21. Pan, S.; Zheng, L.; Nie, R.; Xia, S.; Chen, P.; Hou, Z. Transesterification of glycerol with dimethyl carbonate to glycerol carbonate over Na-Based Zeolites. Chin. J. Catal. 2012, 33, 1772-1777. [CrossRef]

Sample Availability: Samples of the compounds Ca-Mg-Al hydrotalcites intercalated by [Bmim] $\mathrm{OH}$ and pure hydrotalcites are available from the authors.

(C) 2020 by the authors. Licensee MDPI, Basel, Switzerland. This article is an open access article distributed under the terms and conditions of the Creative Commons Attribution (CC BY) license (http://creativecommons.org/licenses/by/4.0/). 